\title{
Surgical Protocol and Short-Term Clinical Outcome of Immediate Placement in Molar Extraction Sockets Using a Wide Body Implant
}

\author{
Stefan Vandeweghe ${ }^{1,2}$, André Hattingh ${ }^{3}$, Ann Wennerberg², Hugo De Bruyn ${ }^{1,2}$ \\ ${ }^{1}$ Department of Periodontology and Oral Implantology, Dental School, Faculty of Medicine and Health Sciences, University \\ of Ghent, Ghent, Belgium. \\ ${ }^{2}$ Department of Prosthetic Dentistry, Malmö University, Malmö, Sweden. \\ ${ }^{3}$ Private Practice for Periodontology and Oral Implantology, Sevenoaks, United Kingdom.
}

\author{
Corresponding Author: \\ Hugo De Bruyn \\ Department of Periodontology and Oral Implantology \\ Dental School, Faculty of Medicine and Health Sciences \\ University of Ghent, De Pintelaan 185, B-9000, Gent \\ Belgium \\ Phone: +3293324017 \\ Fax: + 3293323851 \\ E-mail: hugo.debruyn@ugent.be
}

\begin{abstract}
Objectives: Implant placement in molar extraction sockets can be difficult due to complex multi-root anatomy and the lack of predictable primary stability. The aim of this study was to evaluate the outcome of an 8 - 9 mm diameter tapered implant, designed to be placed in molar extraction sockets.

Material and methods: Patients treated at least 1 year before with a Max ${ }^{\circledR}$ implant (Southern Implants, Irene, South Africa) were invited for a clinical examination. Variables collected were surgical and prosthetic protocol, implant dimension and smoking habits. Peri-implant bone level was determined on peri-apical radiographs and compared to baseline, being implant insertion.

Results: 98 implants had been placed in 89 patients. One implant had failed. Thirty eight patients representing 47 implants (maxilla 26, mandible 21) were available for clinical examination. Mean bone loss was $0.38 \mathrm{~mm}$ (SD 0.48; range - 0.50 - 1.95 ) after a mean follow-up of 20 months (range 12 - 35). Implant success was 97.9\%. Around 30 implants, a bone substitute was used to fill the residual space, but this did not affect the bone loss outcome. Bone loss was only significantly different between maxilla and mandible $(0.48 \mathrm{~mm}$ vs. $0.27 \mathrm{~mm})$ and between the 8 and $9 \mathrm{~mm}$ diameter implants $(0.23 \mathrm{~mm}$ vs. $0.55 \mathrm{~mm})$. A full papilla was present at $71 \%$ of the interproximal sites and irrespective of bone loss.

Conclusions: The Max $^{\circledR}$ implant demonstrated good primary stability, when placed in molar extraction sockets, with limited bone loss over time.
\end{abstract}

Keywords: dental implants; implantation, endosseous dental; single-tooth dental implants; implant-supported dental prosthesis; tooth socket; grafting, bone.

\footnotetext{
Accepted for publication: 4 August 2011

To cite this article:

Vandeweghe S, Hattingh A, Wennerberg A, De Bruyn H. Surgical Protocol and Short-Term Clinical Outcome of Immediate Placement in Molar Extraction Sockets Using a Wide Body Implant.

J Oral Maxillofac Res 2011 (Jul-Sep);2(3):e1

URL: http://www.ejomr.org/JOMR/archives/2011/3/e1/v2n3e1ht.pdf doi: $10.5037 /$ jomr.2011.2301
} 


\section{INTRODUCTION}

The early Brånemark protocol prescribed a healing period of 6 to 8 months between tooth extraction and implant placement [1]. It was believed that this was necessary to avoid infection and to allow for better primary stability at implant placement.

Continuing research lead to the introduction of immediate placement, where the implant is installed in conjunction with tooth extraction. The advantages of immediate placement are the reduced number of surgical interventions and the shortened overall treatment time [2-4]. Additionally, some researchers believe that immediate implant placement may improve the aesthetic outcome due to the reduced risk of bone resorption and the maintenance of gingival and crestal bone architecture $[\underline{3}, \underline{5}]$. A $50 \%$ reduction in horizontal bone width occurs during the first year after tooth extraction. In the vertical dimension, a 2.4 to $4.5 \mathrm{~mm}$ decrease in bone height may occur. This bone resorption is especially pronounced in the molar region and when neighbouring teeth are absent [6-9]. In some cases, the reduction in bone volume is so extensive that it might prevent the delayed placement (16 weeks) of an implant $[10,11]$.

On the other hand, immediate placement has some disadvantages, such as the risk of infection, unpredictable soft and hard tissue response(s), the difficulty to achieve primary stability and the critical positioning of the implant $[12, \underline{13}]$. Especially in subjects with a thin biotype, immediate placement is not recommended due to the risk of recession over time [14]. In periodontallysusceptible patients, immediate implantation might also increase the risk of implant failure [15]. In contradiction to what was initially believed, does immediate placement not prevent the resorption of the buccal bone, which is part of the natural healing process after tooth extraction [16-18].

According to a review by Quirynen et al. [13] immediately placed implants demonstrate a mean failure rate of $6.2 \%$, ranging from $0 \%$ to $40 \%$. However, studies comparing the outcome between immediate and delayed placement, found no significant difference in survival rate [19-22].

Most studies deal with the replacement of a monoradicular tooth. Immediate implantation into a molar socket raises an extra challenge for the clinician, because of the difficulty in positioning the implant, due to the residual inter-radicular bone [23] .

Placing a regular diameter implant in one of the existing root sockets will result in a compromised emergence profile, significant off-angle loading, and the creation of a cantilever effect [24]. A wide diameter implant will enhance bicortical primary stability, increase the surface for osseointegration $[\underline{25}, \underline{26}]$ and will result in a more axial, prosthetically oriented position.

Early publications on wide diameter implants reported more than $20 \%$ implant failures [26, 27] , however more recent studies using surface modified implants report lower failure rates of less than 5\% [28-31]. A moderately rough surface and adapted surgical protocol may promote the anchorage in the bone and decrease implant failures [32,33].

To achieve primary stability in molar extraction sockets more easily, a new wide diameter, tapered implant was introduced. The aim of this study was to evaluate retrospectively the clinical outcome of this implant design when placed immediately into maxillary and mandibulary molar extraction sockets.

\section{MATERIAL AND METHODS}

\section{Implant design}

The Max $^{\circledR}$ implant (Southern Implants, Irene, South Africa) can be 7 to $10 \mathrm{~mm}$ wide and 7,9 or $11 \mathrm{~mm}$ long. It has a tapered design with a $0.8 \mathrm{~mm}$ thread pitch (Figure 1). They have an external hex and a moderately rough surface created by sandblasting and chemically conditioned with solvents of a grade 4 c.p. titanium, with a Sa value of $1.34[\underline{34}, \underline{35}]$. Due to the wide diameter, there is a platform switching of $0.25 \mathrm{~mm}$ in the horizontal plane and a further $0.35 \mathrm{~mm}$ when the 45 degree bevel is included.

\section{Surgical procedure}

Following comprehensive clinical and radiographic examination of the patient and the associated molar tooth, all patients were supplied with formal written

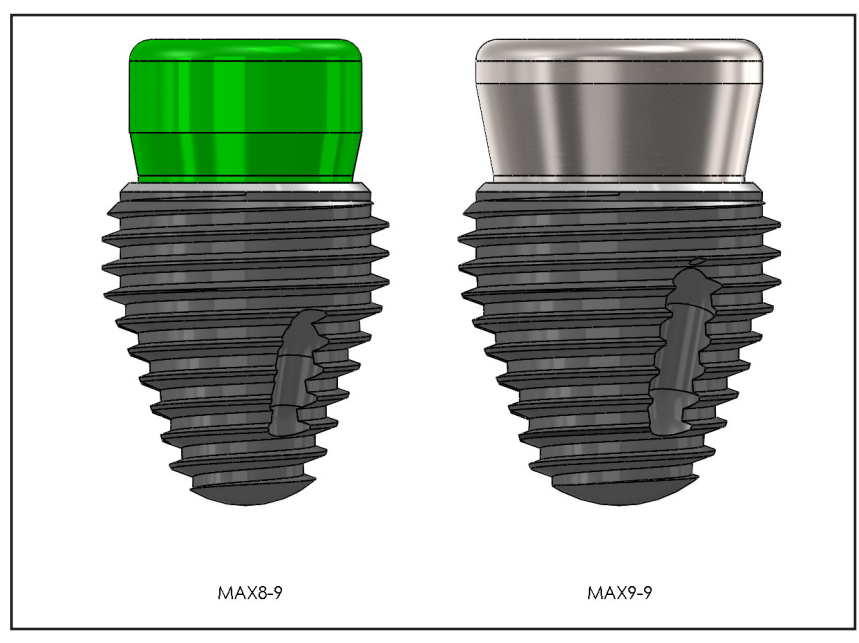

Figure 1. Representation of the $\operatorname{Max}^{\circledR}$ implant. 
treatment plans. The indication for tooth extraction and immediate implant placement was extensive loss of coronal tooth material, preventing conventional prosthetic treatment. The immediate placement approach was only considered for patients with an intact buccal socket wall and a medium or thick periodontal biotype, since it has been shown that a thin biotype is more prone to recession and aesthetical complications and is therefore less suited for immediate placement [36]. Assessment of the biotype was based on the transparency of the periodontal probe as described by De Rouck et al. [37]. A signed consent was required from each patient prior to treatment.

On the day of surgery, local anaesthetic was administered, but no attempt was made to remove the tooth with conventional extraction forceps. As immediate implant placement is critically dependant on the preservation of the perimeter bony walls of the socket, the extractions were carried out by sectioning of the tooth to allow for removal of the roots individually and to avoid potential fracture of any of the associated bony elements, especially the buccal plate (Figure 2).

The crown of the molar was always cut off horizontally. The roots were then carefully separated and the interradicular bone within the socket was used to manipulate the roots, which were then elevated without removal of any bone. Piezo surgery was often utilized to assist with removal of the roots and if root removal proved to be challenging, 4.3 times magnification surgical loupes with fibre optic illumination were used to assist with
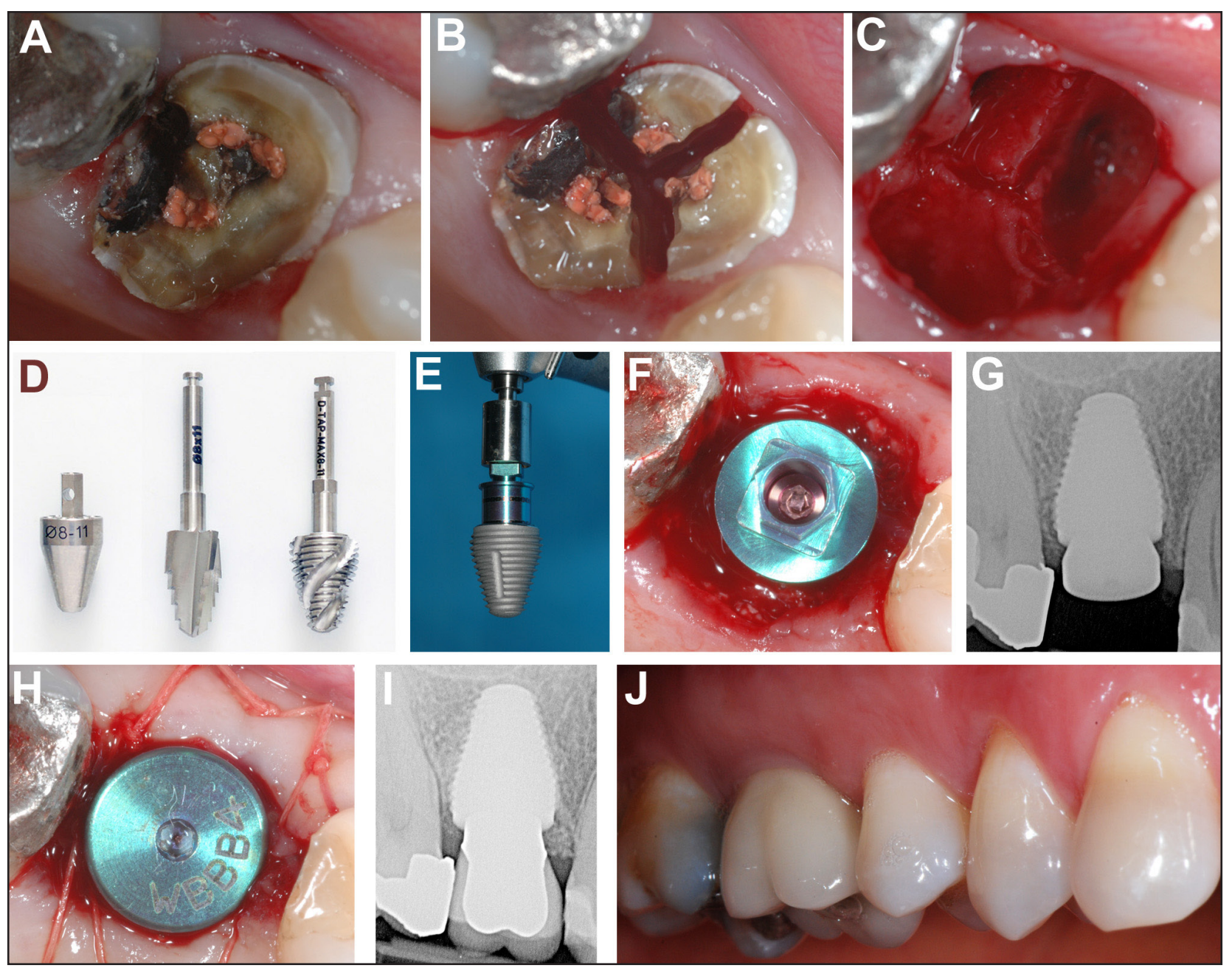

Figure 2. Clinical case representing the surgical procedure:

$\mathrm{A}=$ Caries and substantial loss of tooth material indicated extraction of first molar.

$\mathrm{B}=$ The roots were split to allow atraumatic extraction.

$\mathrm{C}=$ The intact septum was used as a reference to position the first round drill.

$\mathrm{D}=$ Depending on the bone quality, the site was formed using a tapered drill, bone tap or osteotome.

$\mathrm{E}=$ When the implant bed was prepared, the implant was ready to be installed.

$\mathrm{F}=$ If the residual space exceeded $2 \mathrm{~mm}$, a bone graft was used to fill the residual space.

$\mathrm{G}=$ Baseline radiograph, taken immediately after surgery.

$\mathrm{H}=\mathrm{A}$ healing abutment was connected to the implant and the flap was closed.

$\mathrm{I}=$ Radiograph taken 13 months after surgery showing stable bone level around the implant neck.

$\mathrm{J}=$ Intraoral view of the final implant crown. 
the surgery. Once all the roots were removed successfully, the bony socket walls were inspected to confirm the presence of 4 intact outer walls and the absence of any pathology or fenestrations.

Preparation of the inter-radicular bone was then initiated. A round bur was positioned onto the interradicular septum. The point at which the drill was placed was always slightly off-centre towards the lingual in the case of a mandibular molar and often slightly towards the mesial in the case of an maxillary molar. This is to allow for preparation of the implant placement site in a centrally located position, but away from the buccal bone plate. Slight mesially positioned preparation in maxillary molar sockets was only performed, if the available interdental bone between the maxillary first molar and the maxillary second premolar was more than that available between the first and second molar. If this slight adjustment is overlooked, the implant could end up being placed too close to the maxillary second molar. Preparation was then followed by a $1.2 \mathrm{~mm}, 2.00 \mathrm{~mm}$, $2.85 \mathrm{~mm}$ and $3.07 \mathrm{~mm}$ diameter twist drill. This was followed by a 4, 5 and $6 \mathrm{~mm}$ diameter tapered spade drills of the correct length. Specially designed tapered wide diameter drills were then used next, especially in the case of mandibular molars where denser bone was encountered. In the case of a maxillary molar, further preparation of the site was often carried out from this point onwards with dedicated surgical taps. These allow for slow and careful preparation of the bone and enables lateral compaction of the prepared bone as opposed to further bone removal which is commonly anticipated with drilling. This was especially useful in the maxillary molar sockets, where bone quality is usually Type IIIIV. To clarify in more detail, three potential preparation methods were employed after the $6 \mathrm{~mm}$ tapered spade drill. These were carried out using one or a combination of the following:

1) Custom designed osteotomes which correspond to the size of the available implants: 7, 8, 9 mm diameter and 7, 9, or $11 \mathrm{~mm}$ in length. Osteotomes were usually used in a very soft bone, where no drilling is required. They were often useful in second molar sockets with little or no inter-radicular bony anatomy.

2) Custom designed 7,8 , or $9 \mathrm{~mm}$ diameter tapered drills with lengths of 7,9 , or $11 \mathrm{~mm}$. Usually used in hard bone and when there is a very prominent interradicular bony anatomy present.

3) Custom designed surgical taps, which correspond to the size of the available implants: $7,8,9 \mathrm{~mm}$ diameter and 7,9, or $11 \mathrm{~mm}$ in length. Usually used in soft bone and when there is little need to remove more bone with further drilling. Also, used when the greater site preparation control was needed as the taps allow for slow and careful preparation.
Once preparation was complete, one of the custom designed osteotomes was used to place in the osteotomy site and act as a profile gauge. A peri-apical radiograph would then be taken to verify the position and depth of the osteotomy preparation. To compensate for natural bone resorption after tooth extraction, the implant site must allow the implant to be seated $2 \mathrm{~mm}$ below the margin of the intact buccal bony wall and is therefore prepared $2 \mathrm{~mm}$ deeper, compared to delayed implantation [16].

After site preparation, the implant is installed at low speed using the implant surgical unit. In all cases, the implant was primarily seated at $50 \mathrm{Ncm}$ with the implant surgical unit and then finally seated by hand with an implant insertion wrench until the implant platform ended $2 \mathrm{~mm}$ subcrestally. The implant must also be positioned well away from the buccal bony wall of the socket, to avoid damage and recession [36]. Ideally, one would like to see the remaining buccal strut of the interradicular bony septum still intact and butting up against the implant. If the residual socket space was more than $2 \mathrm{~mm}$ wide, a bone graft was used, e.g. a bovine derived xenograft (Bio-Oss ${ }^{\circledR}$, Geistlich, Wolhusen, Switzerland; $\mathrm{Nu}-\mathrm{Oss}^{\circledR}$, Ace Surgical Supply, Brockton, MA, USA) or irradiated allogenic cancellous bone $\left(\mathrm{ICB}^{\circledR}\right.$, Rocky Mountain Tissue Bank, Aurora, CO, USA) $[\underline{38}, \underline{39}]$.

A healing abutment was then connected and tightened. Soft tissue adaptation around the healing abutment was assisted with Vicryl 4.0 sutures and a post-operative peri-apical radiograph was taken with a parallel-aiming device. All patients received a course of antibiotics (2 x Amoxicillin $500 \mathrm{mg} /$ day for 7 days) and analgesics (3 x Ibuprofen $800 \mathrm{mg} /$ day for 3 days, 2 x paracetamol $500 \mathrm{mg}$ / day for 1 day) as well as Corsodyl mouthwash (GlaxoSmithKline Consumer Healthcare, Brentford, Middlesex, UK) after implant surgery. All the cases were followed-up with a postoperative evaluation within 10 - 14 days after surgery.

\section{Patient selection}

All patients, consecutively treated by one experienced periodontist $(\mathrm{AH})$ with one or multiple $\mathrm{Max}^{\circledR}$ implants, were personally invited by phone to attend a clinical research examination. Only implants placed in molar extraction sockets with at least 1 year follow-up postsurgery were included.

Patients, who chose not to attend the examination were asked if the implant was still in function and whether they had experienced any problems with the implant or prosthetic restoration. This method has been described before and was done to detect possible failures or complications [40].

This study was approved by the Ethical Comité of the University Hospital Ghent, Belgium and is in 
accordance with the Helsinki Declaration.

\section{Clinical examination}

Implant data were collected from patient files and clinical examination. Surgical parameters were time of loading, 1 or 2 stage surgery, type of bone graft, implant position and implant dimensions.

Patient related parameters were smoking and gender.

The implant prosthetics were categorized into 3 groups: single crowns, fixed partial prosthesis and fixed full prosthesis. The type of prosthetic retention (cementretained or screw-retained) was also recorded.

The papilla fill was measured according to the papilla index by Jemt [41]. If the neighbouring tooth, crown or pontic was absent, no value was recorded.

\section{Radiographic analyses}

During examination, digital peri-apical radiographs (Vista Scan, Dürr Dental AG, Bietigheim-Bissingen, Germany) were taken using the long-cone paralleling technique and to determine the peri-implant bone loss after comparison with a baseline radiograph taken immediately after surgery. An X-ray holder was used to orient the X-ray beam perpendicular with the implant axis. Radiographic analyses were done by the one independent examiner (SVDW) not involved in the initial implant treatment using DBSWIN software (Dürr Dental AG, Bietigheim-Bissingen, Germany) with an accuracy of $0.1 \mathrm{~mm}$. Radiographs were calibrated using the known thread pitch as a reference. Bone level was determined from implantabutment connection to the first bone-to-implant contact mesial and distal. The mean of both values was taken as the implant bone level. The actual bone loss or bone gain was calculated as the difference between baseline and follow-up.

Each individual implant was dichotomised as either a success (value 1) or a survival (value 0), using a mathematical formula to link bone loss and time. Implants up to one year in function were called "implant bone loss success", when bone loss during the first year was $\leq 1.5 \mathrm{~mm}$; implants longer than one year in function were successful, when bone loss was $\leq 1.5+(0.2 \times$ [Time in months -12$] / 12) \mathrm{mm}$, based on the internationally accepted criteria of Albrektsson and Isidor [42], allowing a maximum of $1.5 \mathrm{~mm}$ bone loss during the first year and $0.2 \mathrm{~mm}$ yearly thereafter.

\section{Statistical analysis}

Statistics were performed with PASW v18 for
Windows (SPSS $^{\circledR}$, Chicago, Illinois, USA). Mann Whitney U-test and Kruskal-Wallis Test were used for bone loss analyses. Chi-Square was used for statistical comparison of implant failure and success rate. $\mathrm{P}<0.05$ was considered statistically significant.

\section{RESULTS}

In total, 98 implants installed in 89 patients answered to the selection criteria. All patients could be reached by telephone and confirmed that their implant was still present. Only 1 implant failed prior to loading, resulting in an overall $98.98 \%$ implant survival rate.

38 patients (12 male, 26 female) with 47 implants were available for clinical examination (Table 1). The mean age was 60 years (SD 11.64, range $25-83$ ). Twenty six implants were placed in the maxilla and 21 in the mandible. A detailed overview of implant distribution according to implant position can be seen in Figure 3 . Table 2 represents an overview of implant length according to implant diameter. In the maxilla, $69.2 \%$ of the implants were $9 \mathrm{~mm}$ in diameter, while in the mandible, $76.2 \%$ of the implants were $8 \mathrm{~mm}$ in diameter. This was significantly different $(\mathrm{P}=0.002)$.

No implant failures occurred in the examined patients. The mean peri-implant bone loss was $0.38 \mathrm{~mm}$

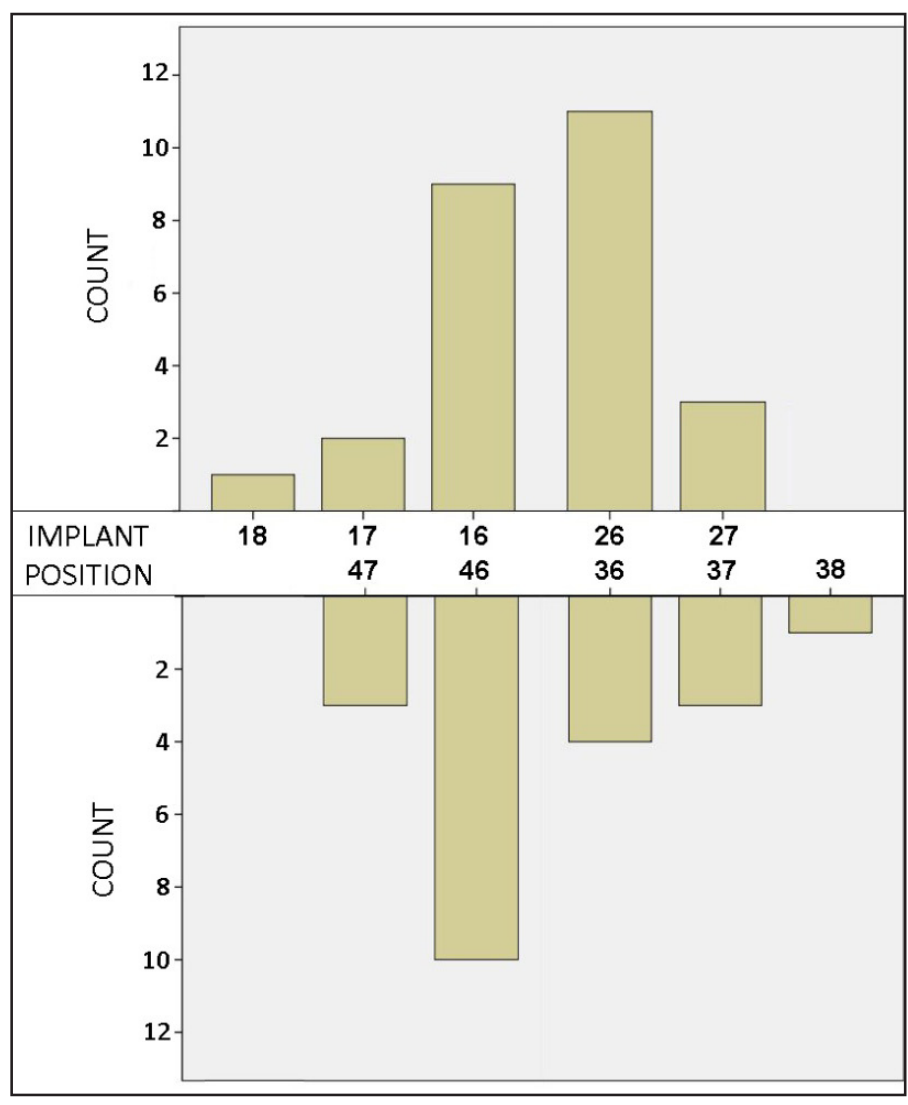

Figure 3. Overview of implant distribution according to implant position. 
Table 1. Table representing frequency distribution, bone loss and implant success for the different variables

\begin{tabular}{|c|c|c|c|c|c|c|c|}
\hline & & $\begin{array}{l}\text { Implants } \\
\text { number }\end{array}$ & $\begin{array}{c}\text { Bone loss } \\
(\mathrm{mm})\end{array}$ & P-value & $\begin{array}{l}\text { Implant } \\
\text { success }\end{array}$ & P-value & $\begin{array}{c}\text { Time } \\
\text { (months) }\end{array}$ \\
\hline \multirow{2}{*}{ Gender } & Male & 15 & $0.41(\mathrm{SD} 0.56$, range $0.00-1.95)$ & \multirow{2}{*}{0.836} & $14 / 15(93.3 \%)$ & \multirow{2}{*}{0.140} & $22(\mathrm{SD} 6.02$; range $14-32)$ \\
\hline & Female & 32 & $0.38(\mathrm{SD} 0.45$, range $-0.50-1.55)$ & & $32 / 32(100 \%)$ & & 19 (SD 5.61; range 12-35) \\
\hline \multirow{2}{*}{ Jaw } & Maxilla & 26 & $0.48(\mathrm{SD} 0.52 ;$ range $-0.50-1.95)$ & \multirow{2}{*}{$0.050^{\mathrm{a}}$} & $25 / 26(96.2 \%)$ & \multirow{2}{*}{0.364} & 21 (SD 6.01; range 12-35) \\
\hline & Mandible & 21 & $0.27(\mathrm{SD} 0.42 ;$ range $-0.05-1.35)$ & & $21 / 21(100 \%)$ & & 20 (SD 5.66; range 12-32) \\
\hline \multirow{2}{*}{$\begin{array}{l}\text { Implant } \\
\text { diameter }\end{array}$} & $8 \mathrm{~mm}$ & 24 & $0.23(\mathrm{SD} 0.42 ;$ range $-0.50-1.35)$ & \multirow{2}{*}{$0.008^{\mathrm{b}}$} & $24 / 24(100 \%)$ & \multirow{2}{*}{0.302} & 18 (SD 3.69; range 12-26) \\
\hline & $9 \mathrm{~mm}$ & 23 & $0.55(\mathrm{SD} 0.50 ;$ range $0.00-1.95)$ & & $22 / 23(95.7 \%)$ & & 22 (SD 6.76; range $13-35$ ) \\
\hline \multirow{3}{*}{$\begin{array}{l}\text { Implant } \\
\text { length }\end{array}$} & $7 \mathrm{~mm}$ & 5 & $0.79(\mathrm{SD} 0.63 ;$ range $0.10-1.55)$ & \multirow{3}{*}{0.205} & $5 / 5(100 \%)$ & \multirow{3}{*}{0.613} & 21 (SD 4.44; range $13-24)$ \\
\hline & $9 \mathrm{~mm}$ & 18 & $0.28(\mathrm{SD} 0.36 ;$ range $-0.50-0.80)$ & & $18 / 18(100 \%)$ & & $20(\mathrm{SD} 4.90$; range $16-32)$ \\
\hline & $11 \mathrm{~mm}$ & 24 & $0.38(\mathrm{SD} 0.51 ;$ range $0.00-1.95)$ & & $23 / 24(95.8 \%)$ & & $20(\mathrm{SD} 6.70$; range $12-35)$ \\
\hline \multirow{2}{*}{ Smoking } & Yes & 2 & $0.83(\mathrm{SD} 1.03$, range $0.10-1.55)$ & \multirow{2}{*}{0.426} & $2 / 2(100 \%)$ & \multirow{2}{*}{0.831} & 19 (SD 7.78; range $13-24)$ \\
\hline & No & 45 & $0.37(\mathrm{SD} 0.46$, range $-0.50-1.95)$ & & $44 / 45(97.8 \%)$ & & 20 (SD 5.81; range $12-35)$ \\
\hline \multirow{4}{*}{ Bone graft } & No & 17 & $0.43(\mathrm{SD} 0.50 ;$ range $-0.15-1.55)$ & \multirow{4}{*}{0.480} & $17 / 17(100 \%)$ & \multirow{4}{*}{0.395} & 19 (SD 3.77; range $13-28)$ \\
\hline & Bio-Oss & 12 & $0.53(\mathrm{SD} 0.59 ;$ range $0.00-1.95)$ & & $11 / 12(91.7 \%)$ & & 25 (SD 7.75; range $14-35)$ \\
\hline & ICB & 14 & $0.18(\mathrm{SD} 0.29 ;$ range $-0.50-0.60)$ & & $14 / 14(100 \%)$ & & 19 (SD 4.48; range $12-26)$ \\
\hline & Nu-Oss & 4 & $0.48(\mathrm{SD} 0.53$; range $0.00-1.20)$ & & $4 / 4(100 \%)$ & & $16(\mathrm{SD} 2.38$; range $12-17)$ \\
\hline \multirow{3}{*}{$\begin{array}{l}\text { Prosthetic } \\
\text { restoration }\end{array}$} & Single crown & 38 & $0.41(\mathrm{SD} 0.45 ;$ range $0.00-1.95)$ & \multirow{3}{*}{0.429} & $37 / 38(97.4 \%)$ & \multirow{3}{*}{0.886} & $20(\mathrm{SD} 6.02$; range $12-35)$ \\
\hline & Fixed partial prosthesis & 6 & $0.27(\mathrm{SD} 0.73 ;$ range $-0.50-1.55)$ & & $6 / 6(100 \%)$ & & 18 (SD 3.66; range $13-24)$ \\
\hline & Fixed full prosthesis & 3 & $0.47(\mathrm{SD} 0.42$; range $0.00-0.80)$ & & $3 / 3(100 \%)$ & & $23(\mathrm{SD} 6.93$; range $19-31)$ \\
\hline \multirow{2}{*}{$\begin{array}{l}\text { Prosthetic } \\
\text { retention }\end{array}$} & Screw-retained & 45 & $0.40(\mathrm{SD} 0.48 ;$ range $-0.50-1.95)$ & \multirow{2}{*}{0.103} & $44 / 45(97.8 \%)$ & \multirow{2}{*}{0.880} & $20(\mathrm{SD} 5.85$; range $12-35)$ \\
\hline & Cemented & 1 & -0.15 & & $1 / 1(100 \%)$ & & 17 \\
\hline
\end{tabular}

aStatistically significant difference in bone loss between maxilla and mandible (Mann-Whitney U test, $\mathrm{P}<0.05$ ).

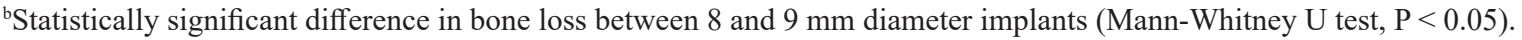

Table 2. Implant distribution according to implant diameter and length

\begin{tabular}{cc|c|c|c}
\hline \multirow{2}{*}{} & & \multicolumn{2}{|c|}{ Diameter $(\mathbf{m m})$} & \multirow{2}{*}{ Total } \\
\cline { 3 - 4 } & & 8 & 9 & \\
\hline \multirow{2}{*}{ Length } & 7 & 2 & 3 & 5 \\
$(\mathbf{m m})$ & 9 & 11 & 7 & 18 \\
& 11 & 11 & 13 & 24 \\
\hline \multicolumn{2}{c|}{ Total } & 24 & 23 & 47 \\
\hline
\end{tabular}

(SD 0.48; range - 0.50 - 1.95), after a mean follow-up period of 20 months (SD 5.75; range $12-35$ ) (Figure 4). There were no significant changes in the bone loss between the different 6 months intervals $(\mathrm{P}=0.487)$ (Figure 5). The overall individual implant success rate was $97.9 \%(46 / 47)$.

All implants were placed following a 1 stage approach and delayed loading. Univariate analysis showed significantly more bone loss in the maxilla (mean $=0.48 \mathrm{~mm}$, SD 0.52, range $-0.50-1.95$ ) compared to the mandible (mean $=0.27 \mathrm{~mm}$, SD 0.42, range - $0.05-1.35)(\mathrm{P}=0.050)$. Furthermore, more bone loss was seen around the $9 \mathrm{~mm}$ diameter implants (mean = $0.55 \mathrm{~mm}$, SD 0.50 , range $0.00-1.95$ ) compared to the 8 $\mathrm{mm}$ diameter implants (mean $=0.23 \mathrm{~mm}$, SD 0.42 , range
- $0.50-1.35)(\mathrm{P}=0.008)$ (Table 1).

At the mesial side, the papilla filled the interproximal space completely at $76.1 \%$ of the sites, more than half at $19.6 \%$ and less than half at $4.3 \%$ of the sites. At the distal side, the papilla filled the interproximal space completely at $62.1 \%$, more than half at $31 \%$ and less than half at $6.9 \%$ of the sites. There was no significant difference in bone loss between the different scores at the mesial side $(\mathrm{P}=0.236)$ or distal side $(\mathrm{P}=0.180)$, or in success rate at mesial $(\mathrm{P}=0.852)$ or distal $(\mathrm{P}=0.316)$ side.

\section{DISCUSSION}

The $98.98 \%$ implant survival is in accordance with other studies on immediate placement reporting survival rates over $92 \%$ after at least 1 year follow-up [르, $\underline{43-53}]$. Although it was partially based on telephonic contact, Vercruyssen et al. [40] demonstrated the reliability of this technique. The survival rate also corresponds to the outcome of an earlier multicenter study using this implant design, reporting a $95.7 \%$ implant survival rate for the immediately placed Max $^{\circledR}$ implants [54]. However, some of the immediate implants in that study 


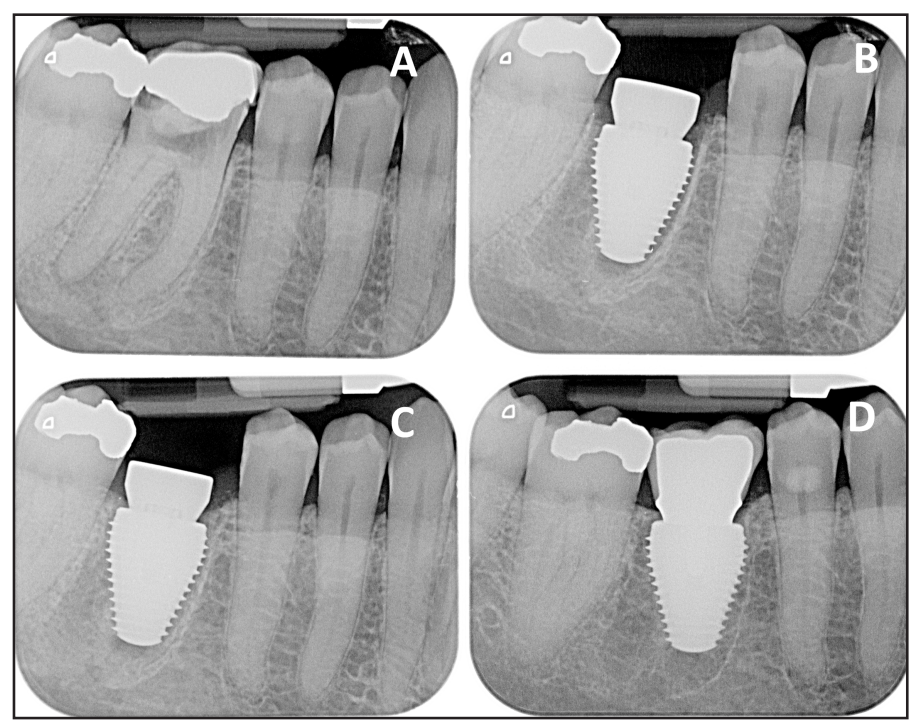

Figure 4. Peri-apical radiographs representing the bone levels around the $\mathrm{Max}^{\circledR}$ implant over time:

A = Pre-operative radiograph. Due to its poor prognosis, the decision was made to extract the tooth.

$\mathrm{B}=$ Baseline radiograph, taken on the day of surgery. The implant is placed slightly subcrestally.

$\mathrm{C}=$ Radiograph taken after 3 months.

$\mathrm{D}=$ Radiograph taken after 2 years of loading. The bone level is stable and situated at the implant neck.

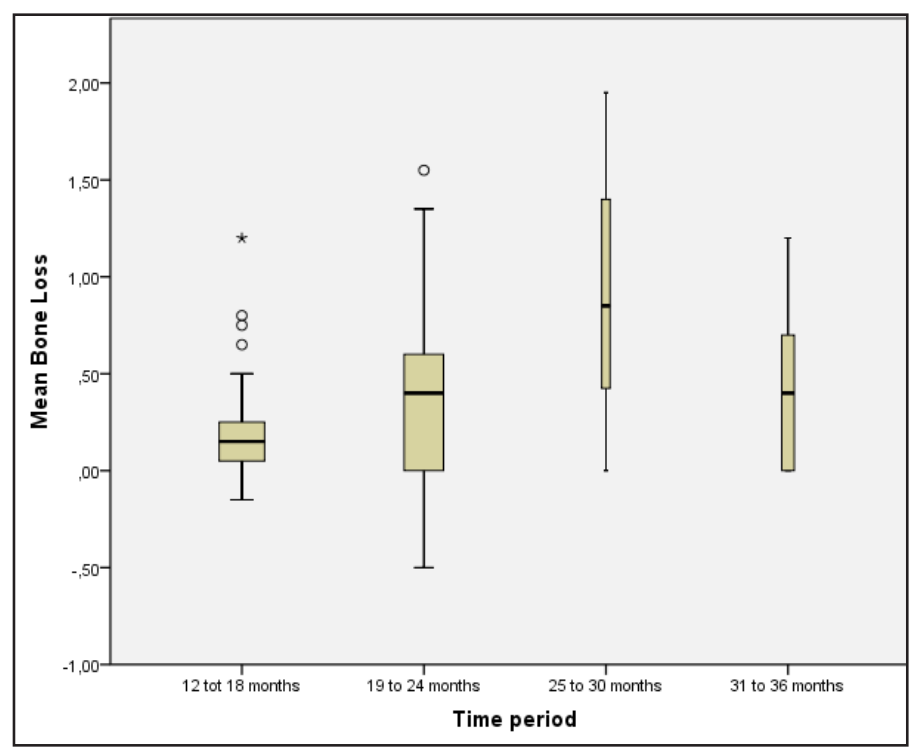

Figure 5. Box-plot representing the mean bone loss and range per 6 months' time interval.

were submerged during healing or immediately loaded, which might explain the lower survival rate in that study and makes comparison not completely valid.

The population in a private practice may differ from the one in clinical research projects executed at academic centres. Although infection control measures were taken before surgery and oral hygiene was adequate, patients were not excluded from the study for certain risk factors as smoking or diabetes. Despite this, these data reflect reality and the outcome is comparable to highly-controlled studies.
Although some authors report more bone loss around wide diameter implants compared to regular diameter implant [55], the amount of bone loss was only $0.38 \mathrm{~mm}$ after at least 1 year follow-up. This is in accordance with other studies and far within the criteria for success $[\underline{29-31}, \underline{56}, \underline{57}]$. Although one could argue that the clinical follow-up is too short, one has to keep in mind that a marked stability of the bone level during the first six months after surgery is normally an indication of a minimal risk for future implant failure or further bone loss unless periimplantitis or traumatic overloading are involved. This being said, it remains of course necessary that the studied implant and presented treatment protocol are scrutinized further after a longer follow-up time for further validation.

Today, very few studies reported on bone loss around implants immediately placed in molar sockets. Bianchi and Sanfilippo [58] reported a 0.75 $\mathrm{mm}$ bone loss after at least 72 months follow-up and Penarrocha et al. [19] reported $0.83 \mathrm{~mm}$ bone loss after 1 year. Prosper et al. [59] reported a bone level of $0.17 \mathrm{~mm}$ after 1 year and 1.01 after 5 years. These results indicate that immediate placement generates limited bone loss, which is stable over time.

Bone loss was significantly lower in the mandible compared to the maxilla, which is in accordance with earlier studies $[20,60]$. Jawbone quality and quantity are more often compromised in maxillary than in mandibular sites and may therefore affect the implant treatment outcome [61].

Wide-diameter implants have reported an increased failure rate, mainly associated with the operators' learning curves, poor bone density, implant design and site preparation, and its use when primary stability had not been achieved with a standard-diameter implant [33]. Innovations in surgical protocol and implant design made their outcome comparable with standard diameter implants. The increased bone loss around the $9 \mathrm{~mm}$ diameter implants can be explained by the fact that $78.3 \%$ of these implants were placed in the maxilla, while $66.7 \%$ of the $8 \mathrm{~mm}$ implants were placed in the mandible.

In $63.8 \%$ of the cases, an additional bone graft was used to fill the residual space of the extraction socket. However, there is no consensus on the indication and the optimal regenerative technique [62]. The success for full bone healing depends on the stabilization of the coagulum, which depends on the distance from the bone to the implant [63-66]. For this reason, some studies advise the use of a bone graft if the jumping distance is more than $2 \mathrm{~mm}[38,39]$.

A full papilla was present at $70.66 \%$ of the interproximal sites. Papilla presence was not 
correlated with bone loss, as confirmed by Degidi et al. [67]. Studies using the same index to evaluate the papilla fill reported a full papilla at $35 \%$ to $78 \%$ of the sites [67-70]. The disadvantage of the Papilla Index of Jemt [41] is that scores are based on the fill of the embrasure space and not on a comparison with the pretreatment appearance of the papilla. This makes comparison with other studies and treatment approaches difficult. However, there is evidence that the final form of the papilla is similar for immediate or delayed placement as well as immediate or delayed restoration [71].

\section{CONCLUSIONS}

Immediate molar replacement, using a wide body $\operatorname{Max}^{\circledR}$ implant, offers good primary stability and limited bone loss over time. However, careful surgery and case selection is recommended to obtain a good result.

\section{ACKNOWLEDGMENTS AND DISCLOSURE STATEMENTS}

The authors declare that they have no conflict of interests.

\section{REFERENCES}

1. Brånemark PI, Hansson BO, Adell R, Breine U, Lindström J, Hallén O, Ohman A. Osseointegrated implants in the treatment of the edentulous jaw. Experience from a 10-year period. Scand J Plast Reconstr Surg Suppl. 1977;16:1-132. [Medline: $\underline{36184]}$

2. Becker BE, Becker W, Ricci A, Geurs N. A prospective clinical trial of endosseous screw-shaped implants placed at the time of tooth extraction without augmentation. J Periodontol. 1998 Aug;69(8):920-6. [Medline: 9736375]

3. Lazzara RJ. Immediate implant placement into extraction sites: surgical and restorative advantages. Int J Periodontics Restorative Dent. 1989;9(5):332-43. [Medline: 2640210]

4. Schwartz-Arad D, Chaushu G. The ways and wherefores of immediate placement of implants into fresh extraction sites: a literature review. J Periodontol. 19970ct;68(10):915-23. [Medline: 9358358]

5. Watzek G, Haider R, Mensdorff-Pouilly N, Haas R. Immediate and delayed implantation for complete restoration of the jaw following extraction of all residual teeth: a retrospective study comparing different types of serial immediate implantation. Int J Oral Maxillofac Implants. 1995 Sep-Oct;10(5):561-7. [Medline: 7591000]

6. Carlsson GE, Bergman B, Hedegård B. Changes in contour of the maxillary alveolar process under immediate dentures. A longitudinal clinical and x-ray cephalometric study covering 5 years. Acta Odontol Scand. 1967 Jun;25(1):45-75. [Medline: 5233859] [doi: 10.3109/00016356709072522]

7. Schulte W, Kleineikenscheidt H, Lindner K, Schareyka R. [The Tübingen immediate implant in clinical studies]. Dtsch Zahnarztl Z. 1978 May;33(5):348-59. German. [Medline: 348452]

8. Johnson K. A study of the dimensional changes occurring in the maxilla following tooth extraction. Aust Dent J. 1969

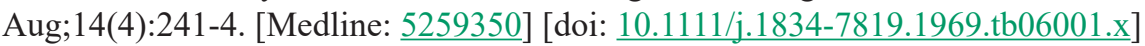

9. Schropp L, Wenzel A, Kostopoulos L, Karring T. Bone healing and soft tissue contour changes following singletooth extraction: a clinical and radiographic 12-month prospective study. Int J Periodontics Restorative Dent. 2003 Aug;23(4):313-23. [Medline: 12956475]

10. Chen ST, Wilson TG Jr, Hämmerle CH. Immediate or early placement of implants following tooth extraction: review of biologic basis, clinical procedures, and outcomes. Int J Oral Maxillofac Implants. 2004;19 Suppl:12-25. Review. [Medline: 15635942]

11. De Wijs FL, Cune MS, De Putter C. Delayed implants in the anterior maxilla with the IMZ-implant system. J Oral Rehabil. 1995 May;22(5):319-26. [Medline: 7616340] [doi: 10.1111/j.1365-2842.1995.tb00779.x]

12. De Rouck T, Collys K, Cosyn J. Single-tooth replacement in the anterior maxilla by means of immediate implantation and provisionalization: a review. Int J Oral Maxillofac Implants. 2008 Sep-Oct;23(5):897-904. Review. [Medline: 19014160]

13. Quirynen M, Van Assche N, Botticelli D, Berglundh T. How does the timing of implant placement to extraction affect outcome? Int J Oral Maxillofac Implants. 2007;22 Suppl:203-23. Review. Erratum in: Int J Oral Maxillofac Implants. 2008 Jan-Feb;23(1):56. [Medline: 18437797]

14. Chen ST, Darby IB, Reynolds EC, Clement JG. Immediate implant placement postextraction without flap elevation. J Periodontol. 2009 Jan;80(1):163-72. [Medline: 19228102] [doi: 10.1902/jop.2009.080243]

15. Deng F, Zhang H, Zhang H, Shao H, He Q, Zhang P. A comparison of clinical outcomes for implants placed in fresh extraction sockets versus healed sites in periodontally compromised patients: a 1-year follow-up report. Int J Oral Maxillofac Implants. 2010 Sep-Oct;25(5):1036-40. [Medline: 20862420]

16. Araujo MG, Sukekava F, Wennstrom JL, Lindhe J. Ridge alterations following implant placement in fresh extraction sockets: an experimental study in the dog. J Clin Periodontol 2005;(32):645-52. [Medline: 15882225] [doi: 10.1111/j.1600-051X.2005.00726.x] 
17. Araújo MG, Sukekava F, Wennström JL, Lindhe J. Ridge alterations following implant placement in fresh extraction sockets: an experimental study in the dog. J Clin Periodontol. 2005 Jun;32(6):645-52. [Medline: 17092218] [doi: 10.1111/j.1600-0501.2006.01317.x]

18. Araújo MG, Wennström JL, Lindhe J. Modeling of the buccal and lingual bone walls of fresh extraction sites following implant installation. Clin Oral Implants Res. 2006 Dec;17(6):606-14. [Medline: 17092217] [doi: $10.1111 / \mathrm{j} .1600-0501.2006 .01315 . \mathrm{x}]$

19. Peñarrocha-Diago M, Carrillo-Garcîa C, Boronat-Lopez A, García-Mira B. Comparative study of wide-diameter implants placed after dental extraction and implants positioned in mature bone for molar replacement. Int J Oral Maxillofac Implants. 2008 May-Jun;23(3):497-501. [Medline: 18700374]

20. Polizzi G, Grunder U, Goené R, Hatano N, Henry P, Jackson WJ, Kawamura K, Renouard F, Rosenberg R, Triplett G, Werbitt M, Lithner B. Immediate and delayed implant placement into extraction sockets: a 5-year report. Clin Implant Dent Relat Res. 2000;2(2):93-9. [Medline: 11359269] [doi: 10.1111/j.1708-8208.2000.tb00111.x]

21. Ribeiro FS, Pontes AE, Marcantonio E, Piattelli A, Neto RJ, Marcantonio E Jr. Success rate of immediate nonfunctional loaded single-tooth implants: immediate versus delayed implantation. Implant Dent. 2008 Mar;17(1):109-17. [Medline: 18332764] [doi: 10.1097/ID.0b013e318166cb84]

22. Paolantonio M, Dolci M, Scarano A, d'Archivio D, di Placido G, Tumini V, Piattelli A. Immediate implantation in fresh extraction sockets. A controlled clinical and histological study in man. J Periodontol. 2001 Nov;72(11):1560-71. [Medline: 11759868] [doi: 10.1902/jop.2001.72.11.1560]

23. Fugazzotto PA. Sinus floor augmentation at the time of maxillary molar extraction: technique and report of preliminary results. Int J Oral Maxillofac Implants. 1999 Jul-Aug;14(4):536-42. Erratum in: Int J Oral Maxillofac Implants 1999 NovDec;14(6):902. [Medline: 10453669 ]

24. Acocella A, Bertolai R, Sacco R. Modified insertion technique for immediate implant placement into fresh extraction socket in the first maxillary molar sites: a 3-year prospective study. Implant Dent. 2010 Jun;19(3):220-8. [Medline: 20523178] [doi:10.1097/ID.0b013e3181dbe2fe]

25. Peñarrocha M, Uribe R, Balaguer J. Immediate implants after extraction. A review of the current situation. Med Oral. 2004 May-Jul;9(3):234-42. Review. English, Spanish. [Medline: 15122126] [FREE Full Text]

26. Shin SW, Bryant SR, Zarb GA. A retrospective study on the treatment outcome of wide-bodied implants. Int J Prosthodont. 2004 Jan-Feb;17(1):52-8. [Medline: 15008233]

27. Eckert SE, Meraw SJ, Weaver AL, Lohse CM. Early experience with Wide-Platform Mk II implants. Part I: Implant survival. Part II: Evaluation of risk factors involving implant survival. Int J Oral Maxillofac Implants. 2001 MarApr;16(2):208-16. [Medline: 11324209]

28. Anner R, Better H, Chaushu G. The clinical effectiveness of $6 \mathrm{~mm}$ diameter implants. J Periodontol. 2005 Jun;76(6):1013-5. [Medline: 15948699] [doi: 10.1902/jop.2005.76.6.1013]

29. Bischof M, Nedir R, Abi Najm S, Szmukler-Moncler S, Samson J. A five-year life-table analysis on wide neck ITI implants with prosthetic evaluation and radiographic analysis: results from a private practice. Clin Oral Implants Res. 2006 Oct;17(5):512-20. [Medline: 16958690] [doi: 10.1111/j.1600-0501.2006.01271.x]

30. Bornstein MM, Harnisch H, Lussi A, Buser D. Clinical performance of wide-body implants with a sandblasted and acidetched (SLA) surface: results of a 3-year follow-up study in a referral clinic. Int J Oral Maxillofac Implants. 2007 JulAug;22(4):631-8. [Medline: 17929525]

31. Krennmair G, Waldenberger O. Clinical analysis of wide-diameter frialit-2 implants. Int J Oral Maxillofac Implants. 2004 Sep-Oct;19(5):710-5. [Medline: 15508987]

32. Lazzara RJ. Criteria for implant selection: surgical and prosthetic considerations. Pract Periodontics Aesthet Dent. 1994 Nov-Dec;6(9):55-62; quiz 64. [Medline: 7488754]

33. Renouard F, Nisand D. Impact of implant length and diameter on survival rates. Clin Oral Implants Res. 2006 Oct;17 Supp1 2:35-51. Review. [Medline: 16968380] [doi: 10.1111/j.1600-0501.2006.01349.x]

34. Albrektsson T, Wennerberg A. Oral implant surfaces: Part 1--review focusing on topographic and chemical properties of different surfaces and in vivo responses to them. Int J Prosthodont. 2004 Sep-Oct;17(5):536-43. [Medline: 15543910]

35. Svanborg LM, Andersson M, Wennerberg A. Surface characterization of commercial oral implants on the nanometer level. J Biomed Mater Res B Appl Biomater. 2010 Feb;92(2):462-9. [Medline: 19957360]

36. Evans CD, Chen ST. Esthetic outcomes of immediate implant placements. Clin Oral Implants Res. 2008 Jan;19(1):73-80. Epub 2007 Oct 22. [Medline: 17956569]

37. De Rouck T, Eghbali R, Collys K, De Bruyn H, Cosyn J. The gingival biotype revisited: transparency of the periodontal probe through the gingival margin as a method to discriminate thin from thick gingiva. J Clin Periodontol. 2009 May;36(5):428-33. [Medline: 19419444] [doi: 10.1111/j.1600-051X.2009.01398.x]

38. Cornelini R. Immediate transmucosal implant placement: a report of 2 cases. Int J Periodontics Restorative Dent. 2000 Apr;20(2):199-206. [Medline: 11203562]

39. Wilson TG Jr, Schenk R, Buser D, Cochran D. Implants placed in immediate extraction sites: a report of histologic and histometric analyses of human biopsies. Int J Oral Maxillofac Implants. 1998 May-Jun;13(3):333-41. [Medline: 9638003$]$ 
40. Vercruyssen M, Marcelis K, Coucke W, Naert I, Quirynen M. Long-term, retrospective evaluation (implant and patientcentred outcome) of the two-implants-supported overdenture in the mandible. Part 1: survival rate. Clin Oral Implants Res. 2010 Apr 1;21(4):357-65. Epub 2010 Jan 22. [Medline: 20105198] [doi: 10.1111/j.1600-0501.2009.01849.x]

41. Jemt T. Regeneration of gingival papillae after single-implant treatment. Int J Periodontics Restorative Dent. 1997 Aug;17(4):326-33. [Medline: 9497723]

42. Albrektsson T, Isidor F. Consensus report of session IV. In: Lang NP, Karring T, editors. Proceedings of the 1st European workshop on periodontology. London, Quintessence. 1994. p. 365-9.

43. Ashman A. An immediate tooth root replacement: an implant cylinder and synthetic bone combination. J Oral Implantol. 1990;16(1):28-38. [Medline: 2074589]

44. Becker W, Dahlin C, Becker BE, Lekholm U, van Steenberghe D, Higuchi K, Kultje C. The use of e-PTFE barrier membranes for bone promotion around titanium implants placed into extraction sockets: a prospective multicenter study. Int J Oral Maxillofac Implants. 1994 Jan-Feb;9(1):31-40. [Medline: 8150510]

45. Brägger U, Hämmerle CH, Lang NP. Immediate transmucosal implants using the principle of guided tissue regeneration (II). A cross-sectional study comparing the clinical outcome 1 year after immediate to standard implant placement. Clin Oral Implants Res. 1996 Sep;7(3):268-76. [Medline: 9151591] [doi: 10.1034/j.1600-0501.1996.070309.x]

46. Cosci F, Cosci B. A 7-year retrospective study of 423 immediate implants. Compend Contin Educ Dent. 1997 Sep;18(9):940-2, 944, 946 passim. [Medline: 9533370]

47. Goldstein M, Boyan BD, Schwartz Z. The palatal advanced flap: a pedicle flap for primary coverage of immediately placed implants. Clin Oral Implants Res. 2002 Dec;13(6):644-50. [Medline: 12519340] [doi: 10.1034/j.1600-0501.2002.130611.x]

48. Gomez-Roman G, Kruppenbacher M, Weber H, Schulte W. Immediate postextraction implant placement with root-analog stepped implants: surgical procedure and statistical outcome after 6 years. Int J Oral Maxillofac Implants. 2001 JulAug;16(4):503-13. [Medline: 11515997]

49. Gomez-Roman G, Schulte W, d'Hoedt B, Axman-Krcmar D. The Frialit-2 implant system: five-year clinical experience in single-tooth and immediately postextraction applications. Int J Oral Maxillofac Implants. 1997 May-Jun;12(3):299-309. [Medline: 9197094]

50. Lang NP, Brägger U, Hämmerle CH, Sutter F. Immediate transmucosal implants using the principle of guided tissue regeneration. I. Rationale, clinical procedures and 30-month results. Clin Oral Implants Res. 1994 Sep;5(3):154-63. [Medline: 7827230] [doi: 10.1034/j.1600-0501.1994.050306.x]

51. Nir-Hadar O, Palmer M, Soskolne WA. Delayed immediate implants: alveolar bone changes during the healing period. Clin Oral Implants Res. 1998 Feb;9(1):26-33. [Medline: 9590942] [doi: 10.1034/j.1600-0501.1998.090104.x]

52. Rosenquist B, Grenthe B. Immediate placement of implants into extraction sockets: implant survival. Int J Oral Maxillofac Implants. 1996 Mar-Apr;11(2):205-9. [Medline: 8666452]

53. Yukna RA. Clinical comparison of hydroxyapatite-coated titanium dental implants placed in fresh extraction sockets and healed sites. J Periodontol. 1991 Jul;62(7):468-72. [Medline: 1656010]

54. Vandeweghe S, Ackermann A, Bronner J, Hattingh A, Tschakaloff A, De Bruyn H. A Retrospective, Multicenter Study on a Novo Wide-Body Implant for Posterior Regions. Clin Implant Dent Relat Res. 2009 Dec 3. [Epub ahead of print] [Medline: 19958373]

55. Ivanoff CJ, Gröndahl K, Sennerby L, Bergström C, Lekholm U. Influence of variations in implant diameters: a 3- to 5-year retrospective clinical report. Int J Oral Maxillofac Implants. 1999 Mar-Apr;14(2):173-80. [Medline: 10212533]

56. Mordenfeld MH, Johansson A, Hedin M, Billström C, Fyrberg KA. A retrospective clinical study of widediameter implants used in posterior edentulous areas. Int J Oral Maxillofac Implants. 2004 May-Jun;19(3):387-92. [Medline: 15214223]

57. Tawil G, Mawla M, Gottlow J. Clinical and radiographic evaluation of the 5-mm diameter regular-platform Brånemark fixture: 2- to 5-year follow-up. Clin Implant Dent Relat Res. 2002;4(1):16-26. [Medline: 11938634] [doi: $10.1111 /$ j.1708-8208.2002.tb00147.x]

58. Bianchi AE, Sanfilippo F. Single-tooth replacement by immediate implant and connective tissue graft: a 1-9-year clinical evaluation. Clin Oral Implants Res. 2004 Jun;15(3):269-77. [Medline: 15142088] [doi: 10.1111/j.1600-0501.2004.01020.x]

59. Prosper L, Crespi R, Valenti E, Capparé P, Gherlone E. Five-year follow-up of wide-diameter implants placed in fresh molar extraction sockets in the mandible: immediate versus delayed loading. Int J Oral Maxillofac Implants. 2010 MayJun;25(3):607-12. [Medline: 20556262]

60. Bryant SR. The effects of age, jaw site, and bone condition on oral implant outcomes. Int J Prosthodont. 1998 SepOct;11(5):470-90. Review. [Medline: 9922739]

61. Friberg B, Jemt T, Lekholm U. Early failures in 4,641 consecutively placed Brånemark dental implants: a study from stage 1 surgery to the connection of completed prostheses. Int J Oral Maxillofac Implants. 1991 Summer;6(2):142-6. [Medline: 1809668]

62. Hämmerle $\mathrm{CH}$, Chen ST, Wilson TG Jr. Consensus statements and recommended clinical procedures regarding the placement of implants in extraction sockets. Int J Oral Maxillofac Implants. 2004;19 Suppl:26-8. Review. [Medline: 15635943] 
63. Akimoto K, Becker W, Donath K, Becker BE, Sanchez R. Formation of bone around titanium implants placed into zero wall defects: pilot project using reinforced e-PTFE membrane and autogenous bone grafts. Clin Implant Dent Relat Res. 1999;1(2):98-104. [Medline: 11359304] [doi: 10.1111/j.1708-8208.1999.tb00098.x]

64. Botticelli D, Berglundh T, Buser D, Lindhe J. The jumping distance revisited: An experimental study in the dog. Clin Oral Implants Res. 2003 Feb;14(1):35-42. [Medline: 12562363] [doi: 10.1034/j.1600-0501.2003.140105.x]

65. Knox R, Caudill R, Meffert R. Histologic evaluation of dental endosseous implants placed in surgically created extraction defects. Int J Periodontics Restorative Dent. 1991;11(5):364-75. [Medline: 1725869]

66. Stentz WC, Mealey BL, Gunsolley JC, Waldrop TC. Effects of guided bone regeneration around commercially pure titanium and hydroxyapatite-coated dental implants. II. Histologic analysis. J Periodontol. 1997 Oct;68(10):933-49. [Medline: 9358360 ]

67. Degidi M, Nardi D, Piattelli A. Peri-implant tissue and radiographic bone levels in the immediately restored single-tooth implant: a retrospective analysis. J Periodontol. 2008 Feb;79(2):252-9. [Medline: 18251639] [doi: 10.1902/jop.2008.070342]

68. Cornelini R, Cangini F, Covani U, Wilson TG Jr. Immediate restoration of implants placed into fresh extraction sockets for single-tooth replacement: a prospective clinical study. Int J Periodontics Restorative Dent. 2005 Oct;25(5):439-47. [Medline: 16250566 ]

69. Juodzbalys G, Wang HL. Soft and hard tissue assessment of immediate implant placement: a case series. Clin Oral Implants Res. 2007 Apr;18(2):237-43. [Medline: 17348889] [doi: 10.1111/j.1600-0501.2006.01312.x]

70. Lindeboom JA, Tjiook Y, Kroon FH. Immediate placement of implants in periapical infected sites: a prospective randomized study in 50 patients. Oral Surg Oral Med Oral Pathol Oral Radiol Endod. 2006 Jun;101(6):705-10. Epub 2006 Mar 22. [Medline: 16731387] [doi: 10.1016/i.tripleo.2005.08.022]

71. Chen ST, Buser D. Clinical and esthetic outcomes of implants placed in postextraction sites. Int J Oral Maxillofac Implants. 2009;24 Suppl:186-217. Review. [Medline: 19885446]

\section{To cite this article:}

Vandeweghe S, Hattingh A, Wennerberg A, De Bruyn H. Surgical Protocol and Short-Term Clinical Outcome of Immediate Placement in Molar Extraction Sockets Using a Wide Body Implant.

J Oral Maxillofac Res 2011;2(3):e1

URL: http://www.ejomr.org/JOMR/archives/2011/3/e1/v2n3e1ht.pdf

doi: $10.5037 /$ jomr.2011.2301

Copyright (C) Vandeweghe S, Hattingh A, Wennerberg A, De Bruyn H. Accepted for publication in the JOURNAL OF ORAL \& MAXILLOFACIAL RESEARCH (http://www.ejomr.org), 4 August 2011.

This is an open-access article, first published in the JOURNAL OF ORAL \& MAXILLOFACIAL RESEARCH, distributed under the terms of the Creative Commons Attribution-Noncommercial-No Derivative Works 3.0 Unported License, which permits unrestricted non-commercial use, distribution, and reproduction in any medium, provided the original work and is properly cited. The copyright, license information and link to the original publication on (http://www.ejomr.org) must be included. 